\title{
THE DARK SIDE OF INTERNATIONAL CROSS-LISTING: EFFECTS ON RIVAL FIRMS AT HOME
}

\author{
MiCHAEL MELVIN \\ MAGALI VALERO
}

\section{CESIFO WORKING PAPER NO. 2174 \\ CATEgORY 6: MONETARy PoliCy AND InTERnAtional FinANCE DECEMBER 2007}

\footnotetext{
An electronic version of the paper may be downloaded

- from the SSRN website: Www.SSRN.com

- from the RePEc website: Www.RePEc.org

- from the CESifo website: www.CESifo-group.org/wp
} 


\title{
THE DARK SIDE OF INTERNATIONAL CROSS-LISTING: EFFECTS ON RIVAL FIRMS AT HOME
}

\begin{abstract}
We analyze the stock price impact of firms' U.S. cross-listing on home-market rival firms. Using an empirical event study approach we find negative cumulative average abnormal returns for the rival firms. The evidence suggests that the dominant effect is that investors see rivals as at a relative disadvantage to the listing firm. As firms cross-list in the US and commit to the increased disclosure and investor protection associated with the US listing, they are better able to take advantage of growth opportunities relative to their non cross-listing counterparts, and this results in negative spillover effects on rival firms.
\end{abstract}

JEL Code: G15.

Keywords: cross-listings, rival firms, growth opportunities.

Michael Melvin

Barclays Global Investors

45 Fremont St.

San Francisco, CA 94105

USA

Michael.melvin@barclaysglobal.com
Magali Valero

University of Michigan - Dearborn

School of Management

19000 Hubbard Drive

Dearborn, MI 48126

USA

mvalero@umd.umich.edu 


\section{THE DARK SIDE OF INTERNATIONAL CROSS-LISTING: Effects on Rival Firms at Home}

\section{Introduction}

When foreign firms list their shares on a U.S. stock exchange, this may affect the stock price of the listing firm. It may also affect stock prices of firms in the same industry and country as the listing firm, as investors revise their expectations of firm values. This paper studies the stock price impact on home-market rival firms of firms' cross-listing in the United States.

Existing empirical evidence indicates that a firm listing its shares in the United States experiences a positive change in its share price at home. A survey of the effects of listing shares abroad is conducted by Karolyi (1998). Overall, evidence indicates that companies experience an increase in home-market value in the month around the listing. Miller (1999) examines the benefits of cross-listing around the announcement of listing and shows positive abnormal returns when a foreign firm announces a U.S. listing. Although there are positive effects of cross-listing on cross-listing firms, it is also important to study the impact of cross-listing on other domestic firms to gauge the real benefits of cross-listing to the domestic economy. In this paper we study the valuation effects of cross-listing on these firms’ primary rivals.

Both positive or negative spillover effects may be experienced by the primary home-market rivals which are not listed in the U.S. On the one hand, the traditional risk sharing explanation for cross-listing predicts a positive risk-sharing benefit on rival firms.

On the other hand, it is also possible that rival firms may be harmed by a firm's U.S. 
listing. The more recent bonding, growth opportunities, and signaling explanations for cross-listing would suggest a negative impact on rival firms.

The conventional explanation for cross-listing has been related to the cross-listing firms' benefit from the overcoming of investment barriers. This risk sharing hypothesis poses that firms benefit from cross-listing in the U.S. since their cost of capital falls with the cross-listing (Errunza and Losq (1985) and Stulz (1999)). In support of this, Foerster and Karolyi (1999) and Errunza and Miller (2000) find a strong negative impact of crosslistings on the cost of capital; and Eaton, Nofsinger and Weaver (2007) show that the cost of capital falls for cross listing firms, and that the size of the fall is related to the disclosure quality of the home country. Reasons for this include their being priced in a global context rather than in the relatively segmented domestic market and also the enhanced liquidity resulting from being traded in the U.S. market. Other local firms can be affected if they now become priced in a global context as barriers to international investing are reduced for them too. If there is also a fall in the cost of capital for rival firms that are not cross-listed, then rivals may benefit from the cross-listing. To the degree that firms are correlated with the listing firm, the cost of capital should also fall for other firms in the country (Alexander, Eun and Janakiramanan (1987); Eun, Claessens and Jun (1995)), thus creating a positive impact on rival firms.

The bonding explanation for cross-listing is related to the additional scrutiny that firms go through by listing on a U.S. exchange. Coffee (1999, 2002) and Stulz (1999) posit that firms cross-list as a means to "bond" with the U.S. market and U.S. laws, setting a mechanism for managers to avoid taking excessive private benefits, and therefore enjoy better access to external financing markets. Reese and Weisbach (2002) 
provide support for the bonding hypothesis as they find that firms from countries with weak investor protection are more likely to cross-list in the U.S., and that after crosslisting they significantly increase their equity offerings both inside and outside the U.S. Additional support for the bonding hypothesis is found in Doidge (2004) and in Doidge et al. (2007) who study ownership structure before a U.S. listing and changes in this ownership around the listing event.

The growth opportunities hypothesis is intrinsically related to the bonding explanation for cross-listing. A U.S. listing improves the protection of minority shareholders by reducing the extent to which controlling shareholders can engage in expropriation, making it easier for firms to raise external capital, and thus improving their ability to take advantage of growth opportunities. In support of this hypothesis, Doidge, Karolyi and Stulz (2004) analyze the difference in firm values for foreign firms that list in the U.S. and those that do not. They find that the value of firms that list in the U.S. is higher than the value of firms from the same country that do not list in the U.S. by $16.5 \%$ on average, and explain the differential by arguing that cross-listed firms are better able to take advantage of growth opportunities. The implication of the growth opportunities and bonding hypothesis for rival firms is that as cross-listing firms are seen as having relatively higher growth prospects, rival firms are seen at a relative disadvantage, and we therefore expect a negative impact on their stock price. If rivals are viewed as firms with relatively lower growth opportunities and greater controlling shareholder control compared to the listing firm, this relative disadvantage could create a negative impact of the cross-listing on the rival firm. 
In the signaling literature, firms cross-list as a means to signal their high quality to investors and distinguish themselves from low-quality rivals. Theoretical models by Fuerst (1998), Moel (1999) and Cantale (1998) predict that firms will list in overseas markets as a means of reducing information asymmetry and signaling their high quality to investors. Using a rational expectations model, Huddart, Hughes and Brunnermeier (1999) find an equilibrium where exchanges engage in a 'race for the top' in which they compete for order flow by raising disclosure requirements and lowering costs of trading. More recently, the theoretical model by Chemmanur and Fulghieri (2006) shows that firms benefit from listing on exchanges with high disclosure standards only if information producers can obtain information about the firms at low cost. Thus firms will list when they have a significant base of low-cost information producers, but would like to enlarge that base or to take advantage of the higher transparency of the foreign exchange. This explanation for cross-listing predicts a negative impact on rival firms. As cross-listing firms distinguish themselves from low-quality rivals, we would expect a negative spillover on rival firms.

Given prior theoretical and empirical work, we believe the impact of a crosslisting on rival firms is ambiguous. While rival firms might benefit from the cross-listing as the risk sharing hypothesis would suggest, rivals could also be seen at a relative disadvantage to the listing firm because of their decision not to list. The benefits or costs of a firm's cross-listing on other country constituents are still issues that need to be explored in order to determine the real benefits of cross-listings to markets as a whole. While we concentrate on the spillover effects that come about to the cross-listing firms' primary rival, there are studies that have explored other closely related issues. 
Karolyi (2004) examines a sample of emerging equity markets and studies the effects of cross-listings on stock market development. He finds that while there are benefits, the benefits come from the cross-listing firms themselves and observes negative spillover effects of cross-listings on the local market for non-ADR firms. Levine and Schmukler (2007), using a panel of 55 emerging countries, find that internationalization has a negative spillover effect on the liquidity of domestic firms.

Fernandes (2003) looks at the impact of cross listings on home market firms when the first ADR is created in a sample of emerging market ADRs. By looking at the first ADR in a country (sometimes thought of as a market liberalization event) and concentrating in emerging markets, he tests the risk sharing hypothesis for his sample firms. As the risk-sharing effects are most likely to accrue to the emerging market firms upon the creation of the first ADR program in the country, the study provides evidence supporting the hypothesis as he finds a positive effect on home-market firms when the first ADR is created. However, by not including developed market firms and more recent cross-listings, it is hard to conclude if the risk sharing effect of a cross-listing on other firms in the country is dominating or dominated by other negative spillover effects.

An additional paper that looks at the effects of cross-listings on other firms is that by Bradford, Martin and Whyte (2002). They analyze the impact of cross-listings on both U.S. rivals and domestic-market rivals, by looking at listing dates. Instead of focusing on a matched rival, they create portfolios of all rival firms in the industry for which data are available, and find a positive impact on U.S. rival firms. Using monthly prices, they do not find an effect on home market rival firms. 
Another concurrent study that addresses related issues is that by Lee (2004). He examines portfolios of firms from emerging markets, that are associated with firms that have listed in the United States, and finds that firms in the same industry as the listing firm tend to have negative abnormal returns when the listing is announced. One of the main differences between our paper and his is that we analyze the impact on the primary rival of the listing firm. We do not use indexes of industry rivals since firms in the same industry might be very different in size and trading frequency. Further, we believe that the effects of firms being viewed at a relative disadvantage with respect to the listing firm, and the risk-sharing spillover effects of the cross-listing on other firms should be more important for similar firms, than for other firms in the industry.

Our study contributes to the literature on cross-listings in several ways. First, we analyze the spillover effects of cross-listing on a specific group of firms from which we expect the strongest effects, namely the firm's primary rivals. Second, we include in our analysis firms from both developed and emerging markets and explore their differences. Developed markets are important to study since the liberalization (or risk-sharing) effect is likely to be smaller on average for this group of firms, and including them in the analysis provides insights with respect to whether a liberalization effect is present. Third, we analyze the impact of cross-listing on rival firms at both the announcement of listing and the listing date itself. This provides insights as to when the spillover effects take place. Although rational expectations would predict no effect on the listing date, we expect an effect as long as there is some positive probability that the listing will not take place. Finally, we analyze cross-sectionally the abnormal returns of rival firms, which provide insights on what the important determinants of those spillover effects are. 
We use a sample of cross-listing firms to examine empirically the effects of crosslisting on rival firms. In Section II will discuss the data and methodology used for empirically testing the rival firm effect of cross-listing. Then in Section III, we present the empirical results that relate to the effects of cross-listing on rival firms. Our findings suggest that rival firms are hurt by the listing of other firms in their industry. Over an 11day window surrounding the listing date, rival firms experience a $-2.20 \%$ mean cumulative abnormal return, which is significant at the $1 \%$ level. Rival firms from developed markets experience a statistically significant $-2.35 \%$ cumulative abnormal return, while emerging market rival firms have a cumulative abnormal return of $-1.44 \%$. The abnormal return for emerging market firms is insignificant, and smaller when compared to their developed market counterparts. This is consistent with there being a risk-sharing effect present, as in emerging markets the positive liberalization effect is expected to be stronger on average than in developed markets. We also find a significant negative impact on rival firms on the day of the announcement of listing. On this day, rival firms experience a $-0.32 \%$ mean abnormal return. In Section IV, we analyze the cross-sectional differences in the abnormal returns of rival firms. The results offer support for a risk sharing benefit being present in emerging market firms. We also find evidence supporting the bonding and growth opportunities explanations for cross-listing. Additionally, we find that the rival firm's size and the number of days elapsed between the announcement of listing and the listing event are important determinants of the abnormal returns of rival firms.

\section{Data and Methodology}


Our sample was constructed by first gathering a list of all foreign firms that listed in the U.S. as Level II ADR , Level III ADR, or directly on the NYSE or NASDAQ; and eliminating those for which there was no data on Datastream ${ }^{1,2}$. We then looked for the date on which these firms announced a forthcoming listing by searching the Lexis-Nexis database and Dow-Jones interactive. We restrict the sample by taking only those firms that have an identifiable announcement date. Next, we classified firms into industries from Datastream's (level 4) industry classification. We then searched for a rival for these firms. We do not use indexes of industry rivals since firms in the same industry might be very different in size and trading frequency. Additionally, as discussed previously the market liberalization effect and the negative spillover effect should be more important for primary rivals than for other firms in the industry. For each firm, we obtained the names of the firms from the same country in the same industry. Rivals were chosen by market capitalization on the day of listing. The rival firm is the firm from the same industry who had the closest market capitalization to the original firm on the day of listing. ${ }^{3}$ Rival firms are firms that were not listed in the U.S. at the time of the listing by the listing firm. The result was a total of 146 firm-rival pairs from 21 countries. The listing dates of the

\footnotetext{
${ }^{1}$ Most foreign companies are traded in the U.S. as American Depositary Receipts. An American Depositary Receipt (ADR) is a negotiable certificate denominated in U.S. dollars that represents the ownership of shares in a non-U.S. company. ADRs may trade on organized exchanges or over-the-counter (OTC) and can be either capital raising or not. Some foreign firms (mostly from Israel and Canada) crosslist in the U.S. markets directly, without going through an ADR program. Our sample consists of both Level II and Level III ADRs, as well as direct listings of foreign firms.

${ }^{2}$ There are four types of ADRs. Level I ADRs trade over-the-counter and require no reconciliation to U.S. Generally Accepted Accounting Principles (GAAP) and so involve minimal disclosure under U.S. Securities and Exchange Commission (SEC) regulations. Level II ADRs are for firms that list on a U.S. exchange but raise no new capital. Level III ADRs are for firms that want to raise capital and be listed on a U.S. exchange. Level II and Level III ADRs require U.S. GAAP reconciliation and full disclosure as with any U.S. firm. Finally, Rule 144A ADRs are for firms that seek private U.S. placements to qualified institutional buyers (QIBs). They do not require GAAP reconciliation or full SEC disclosure.

${ }^{3}$ Other papers in the ADR literature that have created data sets with matched firms and a similar matching criteria as ours include Baker, Nofsinger, and Weaver (2002), who match by country- industry-total assets; Errunza and Miller (2000), who match by country -market capitalization; and Lang, Ready, and Yetman (2003), who match by country- industry -total assets.
} 
original firms range from 1986 to 2002. Table 1 presents descriptive statistics on our sample of firms. ${ }^{4}$

We use an event study approach to measure the impact of a firm's listing on the rival firm. We measure the abnormal returns for the rival around the date that the listing firm listed in the U.S. The methodology for measuring abnormal returns is the following. Let's call firm L the firm that listed in the U.S. and firm R the rival firm, which is not listed in the U.S. Then, normal returns for the rival (firm R) are calculated for a period before firm L lists in the U.S. If we let day 0 be the day that firm L lists (or announces listing) in the U.S., then we calculate normal returns using days -180 to -31 (150 days prior to the event window). To measure normal returns, the market model is applied. The equation estimated is:

$$
R_{i t}=\alpha_{i}+\beta_{i} R_{m t}+\varepsilon_{i t}
$$

where $E\left(\varepsilon_{i t}\right)=0$ and $\operatorname{Var}\left(\varepsilon_{i t}\right)=\sigma_{\varepsilon i}^{2} . R_{i t}$ denotes return on security $\mathrm{i}$ at day $\mathrm{t} ; R_{m t}$ is the return on the market portfolio in period t and $\varepsilon_{i t}$ is an error term with mean zero. $\alpha_{i}, \beta_{i}$, and $\sigma_{\varepsilon i}^{2}$ are parameters to be estimated by ordinary least squares. As a proxy for the market return, we use returns calculated from the corresponding Datastream local market index.

\footnotetext{
${ }^{4}$ As an example of the matching procedure, let's take one firm in our sample, Royal Bank of Canada. We look for other firms in the same industry that are not cross listed at the time of Royal Bank's listing and we find seven matches. Then, we search for the market value of the firm on the day of listing. Royal Bank of Canada has a market value of C $\$ 9554.85$ million. By matching it with the firm with closest market value, the match is Canadian Imperial Bank, with a C\$ 7595.66 million market value. Three of the possible matches have market value of less than $1 / 30$ of the market value of the listing firm. It is very common that when we look at possible matches there are some firms in the industry that are very small compared to the cross-listing firm. As another example, Wolseley, a building company from the UK, has 33 possible matches, of which more than half are less than $1 / 4^{\text {th }}$ of its size.
} 
Abnormal returns are then used to measure the impact of creating an ADR program on the equity value of the firm. In order to measure abnormal returns, we first calculate the normal returns as just described for each firm. Then, using the parameter estimates $\hat{\alpha}_{i}$ and $\hat{\beta}_{i}$ for each firm, we calculate abnormal returns for days -30 to +30 (the event window) by computing:

$$
\hat{\varepsilon}_{i t}^{*}=R_{i t}^{*}-\hat{\alpha}_{i}-\hat{\beta}_{i} R_{m t}^{*}
$$

where $*$ denotes event window variables. ${ }^{5}$ These abnormal returns measure the impact on the equity value of firm R when firm L's ADR starts to trade (or announces trading). The test statistic we use is a standardized abnormal return test due to Patell (1976). This test statistic can be used to test the null hypothesis that the expected value of the standardized abnormal returns is equal to zero against the alternative that the expected value of the standardized abnormal returns is not equal to zero. A precision-weighted cumulative mean abnormal return is also computed. Finally, we report a Generalized Sign Z test.

The test uses the normal approximation to the binomial distribution. The null hypothesis for this test is that the fraction of positive returns is the same as in the estimation period.

\section{The Effects of Cross-listing on Rival Firms}

${ }^{5}$ As a further robustness check, we calculate abnormal returns using the following market model to estimate normal returns:

$$
R_{i t}=\alpha_{i}+\beta_{W i} R_{W t}+\beta_{L i} R_{L t}+\varepsilon_{i t}
$$

where $E\left(\varepsilon_{i t}\right)=0$ and $\operatorname{Var}\left(\varepsilon_{i t}\right)=\sigma_{\varepsilon i}^{2}$. $R_{i t}$ denotes return on security $\mathrm{i}$ at day $\mathrm{t} ; R_{W t}$ is the return on the world portfolio in period t, $R_{L t}$ is the return on the local market portfolio in period t, and $\varepsilon_{i t}$ is an error term with mean zero. As a proxy for the world (local) portfolio we use returns calculated from a Datastream world (local) index. The parameter estimates from this equation for each firm are $\hat{\alpha}_{i}, \hat{\beta}_{W i}$ and $\hat{\beta}_{L i}$. Using these, abnormal returns are estimated as:

$$
\hat{\varepsilon}_{i t}^{*}=R_{i t}^{*}-\hat{\alpha}_{i}-\hat{\beta}_{W i} R_{W t}^{*}-\hat{\beta}_{L i} R_{L t}^{*}
$$

where $*$ denotes event window variables. The results do not vary under this specification. 


\section{III.A. Impact on the Rival Firm around the Listing Date}

Table 2 presents the mean cumulative abnormal returns for windows of days $(-5,-1),(-5,+1),(+1,+5)$ and $(-5,+5)$, as well as the event date mean abnormal return $(0,0)$. The table also presents the number of firms that had positive abnormal returns on that respective day, the Z statistic and the Generalized Sign Z. During an 11 day window surrounding the listing date, we find a negative and statistically significant $-2.20 \%$ abnormal return suggesting that rival firms are hurt by the listing. ${ }^{6}$ We will consider announcement effects in the next section but here we stress that identifying the announcement day when news of the listing is revealed is problematic and subject to great error, so for now we center our estimation around the first day of listing ${ }^{7}$.

One may think that with rational expectations, there should only be an announcement effect and no further effect at the time of the listing. However, there are, at least, two reasons why a listing effect could still exist beyond that realized at the announcement time. First, there is always some positive probability that an announced U.S. listing may not actually occur. A recent case in point is that of BMW, the German auto firm, who decided not to follow through with an announced U.S. listing ${ }^{8}$. Second, the risk-sharing effects of a U.S. listing may not be realized until the U.S.-traded shares are available for trading.

\footnotetext{
${ }^{6}$ In contrast, we find a positive event day mean abnormal return for the listing firms in our sample.

${ }^{7}$ For a discussion of the complications of identifying announcement dates of future cross-listings see Foerster and Karolyi (1999).

${ }^{8}$ Even if the listing does take place, as long as there is a positive probability that it does not take place we would see both listing and announcement effects from cross-listing. Many firms have "postponed" their ADR programs creating uncertainty that the listing will actually take place, for example, both Bayer AG and Mahanagar Telephone Nigam Ltd postponed their NYSE listings.
} 


\section{III.B. Impact on the Rival Firm around the Announcement Date}

We next study the impact on the rival firms of the announcement of a forthcoming U.S. listing. The results for the announcement dates should be taken with caution since identifying the announcement dates is subject to great error, and it may well be that the listing event is a more reliable date for analysis. Announcement dates were collected by looking at the first time there was an announcement of the forthcoming U.S. listing on either the Lexis-Nexis database or Dow-Jones Interactive. Table 3 presents the mean cumulative abnormal returns for the rival firms around the announcement date. The mean cumulative abnormal return around the $(-5,5)$ window is $-0.45 \%$, a value that does not differ significantly from zero. On the announcement date, we find a significant $-0.3 \%$ abnormal return for rival firms. So only on the day that the public learns of the planned U.S. listing is there a statistically significant announcement effect. ${ }^{9}$

\section{III.C. Impact on Emerging vs. Developed Market Firms}

The impact of cross-listing on rival firms from emerging markets might differ from those of firms in developed markets. In international asset pricing models (Alexander, Eun and Janakiramanan (1987)) the additional risk premium associated with international restrictions to capital flows diminishes with the cross-listing. It follows that the reduction in the cost of capital for the cross-listing firm should be strongest for those firms coming from countries with stronger investment barriers. Although classifying countries by

\footnotetext{
${ }^{9}$ As a robustness check, we estimate the listing effect using the same estimation window as used for the calculation of the announcement effect. Since during these dates there was no announcement of the firm's intention to list, this should be a clean measure of the normal returns of the firm. Next, since there are some firms for which the announcement of a future U.S. listing fell during the listing event window, we eliminated those firms. Then an event study around the listing date is performed to see whether there is an impact on the rival firm. The results reinforce our previous findings. The mean cumulative abnormal return around a $(-5,5)$ window is $-2.08 \%$ for the rival firms in our sample.
} 
segmentation is a difficult task (see Bekaert and Harvey (1995)), we assume that in general emerging markets are more segmented than developed markets. Thus, everything else equal we would expect the cost of capital to fall by more for firms from emerging markets when compared to firms from developed markets, as the investment barriers overcame by the cross-listing are larger on average in emerging markets than in developed markets.

If stock price valuations associated with a U.S. cross-listing are dominated by a negative spillover effect, and if there is a market liberalization event present, then the post-listing price for rivals not listed in the U.S. should fall by more for rival firms from developed markets than the decrease for rival firms from emerging markets. This testable hypothesis helps disentangle the two effects studied. If there is a market liberalization effect, then we should expect differences between emerging and developed market firms, even if the negative spillover effect dominates the stock price valuation.

We subdivide the sample into the 25 emerging market rivals, and the 121 developed market rival firms. The results are shown in Table 4. Panel A shows the results for listing dates, and Panel B for announcement dates. The mean cumulative abnormal returns over the $(-5,5)$ day window for the developed and emerging sample are $-2.35 \%$ and $-1.44 \%$ respectively. The results for rival firms from emerging markets are not statistically different from zero. The evidence of a negative and persistent effect of the listing on rivals is stronger for firms in developed markets than those in emerging markets. This result suggests that the negative spillover effect is more important than the positive effect associated with a market liberalization, although the differences between emerging and developed market rival firms are consistent with the market liberalization 
effect being present and more important in emerging markets, so that there is no significant negative effect for these firms. We performed a test of the difference of the means of the two subsamples and found no significant results ${ }^{10}$. The cross-sectional analysis in the next section will provide more insight on the differences between the two groups. Panel B of Table 4 shows that the mean cumulative abnormal return on the announcement date is $-0.31 \%$ for developed market firms and $-0.38 \%$ for emerging market firms. Again, the results for emerging market firms are insignificant, as are the tests of the differences between the two groups.

\section{Cross-sectional Differences in Abnormal Returns}

While the two effects discussed, the positive spillover effect due to liberalization and the negative spillover effect that could be due to firms being viewed at a relative disadvantage predict that the cross-listing effects on rival firms is indeterminate, our empirical results show that rival firms tend to be hurt by the listing. This suggests that either the negative effect that rival firms experience because of relatively lower growth prospects or a lower quality connotation is stronger than the positive liberalization effect, or that there is only a negative effect on rival firms and no positive liberalization effect. We analyze which of these two possibilities is true in this section, as we explore the cross-sectional differences in abnormal returns for rival firms for both listing and announcement dates. In section A, we present tests related to the risk sharing hypothesis. In section $B$, we present tests related to the negative spillover effect. Section $C$ tests both hypothesis simultaneously.

\footnotetext{
${ }^{10}$ Miller (1999) studies the market reaction to ADR listing announcements in the U.S, and finds that firms from emerging markets experienced nearly double the cumulative abnormal returns of firms from developed markets. The difference, however, was not statistically significant.
} 
The general model used for analysis is of the following form:

$$
C A R_{(-5,5)}=\alpha+\beta E+\sum \gamma V A R+\sum \delta C O N T R O L S+e
$$

Where $\operatorname{CAR}_{(-5,5)}$ refers to the cumulative abnormal returns for a firm between dates -5 and +5 relative to the listing or announcement date, $\mathrm{E}$ is a dummy variable that equals one if the firms is from an emerging market and 0 otherwise; VAR are variables that we will use to test the hypotheses; and CONTROLS are a set of variables that may impact the return generating process as well. ${ }^{11}$

We use three other control variables in the regression specification besides the Emerging market dummy. First, the size of the rival firm, measured as the market capitalization of the firm on the day of listing or announcement of listing, respectively, for the listing and announcement event cross-sectional regressions. The market capitalization data is gathered from Datastream. Since larger firms are more likely to cross-list in the future (see Pagano et. al., 2002) then the negative effects that accrue to rival firms should be smaller for this group of firms. Therefore, we expect a positive coefficient on this variable that indicates that larger firms experience less negative effects of their rivals' cross-listing. The second variable we use as a control variable is the proportion of sales abroad. Pagano, et al (2002) identify both the size of the firm and the proportion of sales abroad as the two characteristics that most impact the likelihood of cross-listing. As rival firms with higher foreign sales to total sales are more likely to cross-list in the future we might expect a different impact of the listing on firms with high or low foreign sales to total sales. We collect the proportion of sales abroad as of the

\footnotetext{
${ }^{11}$ We thank an anonymous referee for suggesting this cross-sectional model.
} 
fiscal year-end prior to the cross-listing from Worldscope ${ }^{12}$. Finally, the third control variable is the number of days that passed between the announcement of listing and the actual listing. As discussed earlier, we could possibly observe an effect on the rival firm at both the listing and at the announcement event. However, these effects could be different depending on how far away the listing and the announcement day are. The more distant the two dates are, the greater the uncertainty that the listing will actually take place. We test the hypotheses using the OLS model of equation (3) and Newey-West heteroskedasticity-consistent standard errors.

\section{IV.A. Positive Spillover Effects}

In the international asset pricing model of Alexander, Eun, and Janakiramanan (1987) there is an additional risk premium associated with segmented markets, and when investment barriers are reduced this risk premium diminishes as risk is shared by a larger investor base. ${ }^{13}$ Stulz (1999) argues that globalization reduces the cost of capital for all firms in the country. Although globalization may be a slow process, the date of the first ADR has been thought of as a liberalization event, since the first ADR represents a firm overcoming country restrictions and foreign investment barriers. To the degree that an ADR represents an overcoming of investment barriers only for similar firms, the ADR listing would represent an industry-liberalization event. However, we might also think of an ADR as a firm-specific liberalization effect, where the cost of capital falls for crosslisted firms but not for their home-listed rivals. In this case one would expect the negative

\footnotetext{
${ }^{12}$ Because of the imposition of this control variable, and other company characteristics variables used later on in the analysis, the sample size for the cross-sectional analysis falls to 70 observations. However, we redid our event study analysis for these 70 firms and the results from the previous section were similar in terms of magnitude and significance of the coefficients with respect to the full sample of firms.

${ }^{13}$ Empirical evidence that the cost of capital falls with the cross-listing includes Foerster and Karolyi (1999), Errunza and Miller (2000) and Eaton, Nofsinger and Weaver (2007).
} 
spillovers to dominate share pricing so that the price of the rival firm would fall. If liberalization is an industry event, the impact on the price of the rival firm depends on whether the effect of the lower cost of capital is stronger than the effect of the rivals being seen as lower quality firms relative to the listing firm. Further, if an ADR is a firmspecific liberalization event, then we should observe that the listing hurts rival firms as there is only the revision of quality and growth opportunities to be priced.

Theory suggests that there might be a positive impact of the listing on rival firms if the cost of capital falls for all firms that are correlated with the listing firm as risk is shared by a greater number of shareholders. We found a net negative impact of the listing on rival firms on average. In this section, we explore cross-sectional differences in abnormal returns of rival firms to see if there are individual firm differences that vary systematically with the determinants of the liberalization effect..

\section{IV.A.1. Correlation with the Listing Firm}

According to the risk sharing hypothesis there should be a positive impact of the listing on rival firms, and the impact should be stronger for rivals whose returns are more correlated with the listing firm. This hypothesis predicts a positive impact on the listing firm as investment barriers are overcome with the U.S. listing. To the degree that these barriers are defeated also for similar firms in the industry, they should also benefit. The model by Eun, Claessens, and Jun (1995) predicts a "spill-over effect” of international listing that is greater for firms more highly correlated with the listing firm. We investigate whether the abnormal returns that firms experience depend on the correlation of their returns with the listing firm prior to the listing. We measure correlation between the two firms' (lister/rival) returns during the estimation window period (days -211 to - 
31) around the listing and announcement dates. Results are reported in Model 1 of Table 5. We find no relationship between correlation and abnormal returns of the rival, for either listing (in Panel A) or announcement (in Panel B) dates. In Model 2, in addition to the correlation between the two firms' returns we include an interaction dummy, correlation*emerging. In this model 'correlation' measures if there is a different relationship between abnormal returns and correlation for developed market firms, and the interaction term measures the relationship for emerging market firms. We would expect the effect of correlation on returns of emerging-market rivals to be stronger than that of developed since the risk sharing effects should particularly accrue to these firms in segmented markets. The results of Model 2 are supportive of the risk sharing hypothesis at the time of announcement of cross-listing: strong positive effect of correlation on abnormal returns of rivals for emerging market firms, with no effect for developed market firms. Further, we find a negative coefficient on the emerging market dummy that suggests that there are other characteristics of emerging markets that matter for abnormal returns of rivals too. The model is supportive of significant differences among emerging and developed market firms.

\section{IV.A.2. Time and Market Integration}

Next, we split the sample by date of listing. We propose that there should be a positive impact on rivals in earlier years, as the countries are being liberalized. As the markets become more integrated, this positive liberalization effect should fall. The negative spillover explanations for cross-listing do not predict differences on rival firms from early or late listings. We construct a variable called "Time of listing”, which equals 1 if the firm listed in the earliest year in our sample (1986), equals 2 for the following 
year (1987), and so on until the last value of 17 (corresponding to the year 2002). We then run a regression and use as independent variable "Time of listing". The results presented in Model 3 of Table 5 show that the coefficient of "time of listing" is not significant. In Model 4 we include an interaction term time of listing*emerging to try to capture the difference in emerging market firms. Once again, the coefficient of "Time of Listing” is not significant, as neither is the interaction term. Although the coefficients for 'time of listing' are not significant under any specification, the coefficient signs correctly capture the risk sharing hypothesis predictions, where late listings are more negatively impacted by the listing, especially in the case of emerging markets.

Finally, Model 5 in Table 5 includes all the variables used for testing the risk sharing hypothesis used in Models 1-4. The significant relationship between correlation and abnormal returns for rivals from emerging markets at the time of the announcement of listing are robust to the introduction of the other variables. Although our previous results in Tables 2 and 3 suggest that the negative spillovers dominate share pricing, the results in Table 5 show support for a risk sharing benefit taking place among rival firms in emerging markets at the time of the listing announcement. The results of Table 5 also suggest that the size of the rival firm is an important determinant of its abnormal returns, as we find a positive relationship between size and abnormal returns of rival firms.

\section{IV.B. Negative Spillover Effects}

In Section III, we observe a net negative valuation impact of cross-listing on rival firms. Why are rival firms hurt with the cross-listing? Stulz (1999) argues that by crosslisting firms identify themselves from "losers" that are left behind. These domestic firms 
are at a relative disadvantage since they chose not to bond with global capital markets. By cross-listing on the NYSE or Nasdaq, foreign firms commit to higher disclosure and greater respect for minority shareholders' rights, since the listing requires the firm to reconcile its financial statements to the U.S. GAAP, to comply with the U.S. SEC, and to meet the requirements of the exchange on which it lists. Doidge, Karolyi and Stulz (2004) argue that the positive valuation effect of creating ADR programs stems from the enhanced ability of these firms to take advantage of growth opportunities as they bond with the U.S. market. A U.S. listing enhances the protection of investors and reduces the agency costs of controlling shareholders. With lower agency costs firms will have greater access to outside finance and will be in a better position to fund projects and to take advantage of growth opportunities. In this section we test whether the negative valuation impact that rivals experience is related to the bonding hypothesis for cross-listing, as Stulz (1999) suggests.

\section{IV.B.1. IndustryDeterminants of Negative Spillover Effects}

We first look at the different outcomes on rival firms from different industries. According to the bonding hypothesis, rival firms should be affected depending on whether or not the listing firm and the rival are in a high or low growth industry. In particular, the relative disadvantage of firms that chose not to bond with the U.S. market should be stronger in industries with higher growth opportunities, as firms that cross-list from these industries by bonding with the U.S. market, will have more external finance accessible to fund their growth. We expect stronger positive effects on listing firms from high growth industries, as they are better able to take advantage of growth opportunities 
than firms from low growth industries. Similarly, we expect stronger negative effects on rival firms from high growth industries, since they are at a relatively greater disadvantage than their low growth industry counterparts.

Following Bekaert et al. (2007) who use country price/earnings ratios as measures of country growth opportunities, we measure an industry's growth opportunities with its $\mathrm{P} / \mathrm{E}$ ratio. In particular, we measure an industry's growth opportunities by looking for the monthly P/E ratio in Datastream for each firm's particular industry and country on the month prior to the announcement date. We expect to find that rival firms from industries with higher growth opportunities (a higher industry P/E ratio) are at a relatively larger disadvantage from the listing and hence they experience a more negative effect (a negative coefficient). The results in Model 1 of Table 6 support this proposition. Only the results for announcement dates are statistically significant, however both the listing date and announcement date regressions have the correct coefficient sign. In Model 2 of Table 6 we include an interaction term of the industry's P/E with the emerging market dummy. The results suggest that the effect of industry $\mathrm{P} / \mathrm{E}$ on abnormal returns is smaller for emerging market firms. This is consistent with a positive risk sharing effect being present in emerging markets.

\section{IV.B.2. Country Determinants of Negative Spillover Effects}

According to the bonding hypothesis, by listing in the U.S. firms 'bond' with the U.S. laws, and it is this increased minority shareholder protection that results in their better access to capital markets. The manager of a firm will therefore cross-list when the increased growth opportunities from the cross-listing are larger than the costs associated with a reduced level of expropriation. In support of this hypothesis, Reese and Weisbach 
(2002) show that non-U.S. firms that cross-list in the U.S. obtain better access to outside capital markets because the U.S. regulatory system improves the protection of minority shareholders. Firms should then benefit differently from the cross-listing depending on their increased level of minority shareholder protection. We therefore expect a crosssectional difference in the impact on listing firms and their rivals from countries with distinct minority shareholder protection levels. Other things equal, rival firms from countries with weak minority shareholder protection would be at a stronger relative disadvantage compared to rivals from countries with stronger minority shareholder protection. We thus predict a stronger price decrease for rival firms associated with a listing firm that has a stronger increase in minority shareholder protection, as they would be at a greater relative disadvantage. We use six different measures of investor protection in the home country: legal tradition, rule of law, efficiency of the judicial system, risk of expropriation, corruption, and anti-director rights.

As a first measure of country corporate governance, we construct a dummy variable that equals one whenever the listing firm is from a country with civil law tradition, and 0 if it is from a country with common law tradition. Based upon prior research (La Porta et. al.(1997, 1998, 2000)), we expect to find that rival firms from countries with civil law tradition should be hurt more by the listing than rival firms from common law tradition, since the increase in shareholder protection from the listing is greater in the former case. The rule of law measure ranges from zero to 10, with 10 being a high law and order tradition. The efficiency of the judicial system measure ranges from zero to 10 , with 10 representing high efficiency levels. The risk of expropriation index ranges from zero to 10 , with 10 representing the lowest expropriation risk. Legal 
tradition, rule of law, efficiency of the judicial system and risk of expropriation are taken from La Porta et. al. (1998), where more detailed descriptions can be found. We measure corruption using the Transparency International Corruption Perceptions Index (CPI) 2002. The index measures how the public perceives the level of corruption of their public officials and politicians, and it ranges from 0 to 10 , with 10 being a highly clean country with no perceived corruption. Finally, the anti-director rights index ranges from 0 to 6 , where 6 represents the strongest shareholder rights in the home country. This index is taken from Djankov et al. (2005).

Our hypothesis is that, other things equal stronger price decreases should be observed for rival firms associated with a listing firm that has a stronger increase in minority shareholder protection, as they would be at a stronger relative disadvantage. Therefore, we expect a positive relationship between the level of minority shareholder protection at home and abnormal returns of the rival. We thus predict positive coefficients on rule of law, corruption, antidirector, efficiency of the judicial system, and risk of expropriation, as these variables are higher for better protection of minority shareholders. We expect a negative coefficient on the civil law dummy.

The results are reported in Table 7. In Models 1-6 we regress each variable against abnormal returns one at a time since they all measure investor protection and are highly correlated, and we include all variables in Model 7. Out of the 12 regressions in Table 7, 5 have the predicted coefficient sign, 2 have the opposite coefficient sign, and in 5 the coefficient is not significant. The results suggest that these measures of country minority shareholder protection might be confounded with some other important variables that determine abnormal returns. It is thus better to analyze this issue in a multivariate setting. 
In Section IV C we will introduce in the regression country, industry, and firms specific variables. For now, we note that in Model 7, where all variables are included, support is found for the bonding and growth opportunities hypothesis at the time of listing. Additionally, size is still an important determinant of abnormal returns at the time of listing: larger rival firms are hurt by less with the listing. Finally, the coefficient for the number of days between the listing and the announcement of listing suggests that, as there is more time between the announcement and the listing, rival firms experience more negative abnormal returns.

\section{IV.B.3. Company Determinants of Negative Spillover Effects}

Other things equal, the growth opportunities hypothesis predicts that the benefits from cross-listing should be greater for those firms that have the greatest growth prospects. As these firms cross-list as a means to reduce agency costs, get greater access to outside finance, and thus take advantage of their growth opportunities, their rivals are negatively impacted. Their decision not to list puts them at a disadvantage compared to their cross-listing counterparts. This effect should be stronger for high growth firms that require more equity capital for growth. We expect that rival firms with better growth prospects are more negatively impacted by the listing.

We use three measures of the rival firm's growth opportunities: the price to earnings ratio, their one year sales growth, and the market to book ratio. We obtain each rival's P/E ratio on the month prior to the announcement from Datastream. We obtain the one year sales growth for the rival firm in the fiscal year ending prior to the listing (or announcement) date from Worldscope. Sales growth has also been used in the literature to proxy for a firm's growth opportunities (Doidge, Karolyi and Stulz (2004); Doidge, et 
al. (2007); Billett, King and Mauer (2007)). Finally, market to book ratio is as of the fiscal year ending prior to the listing (announcement) date and it comes from Worldscope. The measure has been used to proxy for Tobin's Q as a measure of investment opportunities. Billett, King and Mauer (2007) use it as a proxy for growth opportunities. Higher P/E ratio, higher growth, and higher M/B proxy for greater growth opportunities.

We hypothesize that rival firms with greater growth opportunities are seen at a stronger relative disadvantage and they should be impacted more. Hence, we expect the coefficient on these variables to be negative. Further, the effects of these variables in emerging markets should be less strong, since we have both a growth opportunities and a risk sharing effect working against each other there. Therefore, we expect a positive coefficient on the interactive variable of the rival firm's growth opportunities with the emerging market dummy.

The results are presented in Table 8. In all cases of significance the coefficients have the signs that support the previously discussed hypothesis. There seem to be significant effects at both the listing and the announcement dates. There are stronger negative effects associated with the cross-listing for higher growth rival firms, compared to lower growth rival firms. As in other cross-sectional regressions, size and the number of days between the listing and the announcement date seem to play an important role in explaining listing-date abnormal returns.

\section{IV.C. Risk Sharing Vs. Growth Opportunities Hypothesis}


The previous two sections show support for both the risk sharing and the growth opportunities hypothesis. We found that rival firms from emerging markets that are more correlated with the listing firm are associated with more positive abnormal returns, supporting the risk sharing hypothesis. We also found that firms in high growth industries are affected more, which supports the growth opportunities hypothesis; however this effect is smaller for emerging market firms, in defense of the risk sharing hypothesis. In addition, rival firms with stronger growth opportunities, as measured by their higher $\mathrm{P} / \mathrm{E}$ ratios, sales growth, and $\mathrm{M} / \mathrm{B}$ ratio, have more negative abnormal returns from the listing, consistent with the growth opportunities hypothesis. The effect of the level of shareholder protection in the home country on abnormal returns of rival firms is indeterminate, as it depended on the measure of protection used, and we suspect is due to other variables not being included in the same model. In this section we simultaneously test both hypotheses by regressing abnormal returns of rivals on variables that can be linked to both the risk sharing and the growth opportunities hypothesis. We choose the variables from each section that better explain abnormal returns. To test risk sharing, we use correlation and the interaction term correlation*emerging. To test growth opportunities, we use rule of law (for country corporate governance), industry P/E (for general-industry growth opportunities), and firm P/E and one-year growth (as firm measures of growth opportunities). We also include the control variables used in other specifications: emerging, size of the rival firms, number of days between the announcement and the listing, and foreign sales to total sales.

The results, presented in Table 9, are strong in that they are consistent between announcement and listing day abnormal returns. Once all variables are included in the 
regression, we find that firm-specific growth (as opposed to corporate governance rules or industry growth) is the most important determinant of abnormal returns on rival firms. Specifically, higher growth rivals are affected by more from the cross-listing. This is consistent with the growth opportunities hypothesis as rivals with greater growth potential would be at a greater disadvantage from the listing, and hence they are hurt by more from the listing event. We note also that the insignificant coefficient of the corporate governance variable does not depend on our choice of the variable. We tried the same specification with each of our six corporate governance variables and in no case was the coefficient of this variable significant. The coefficient for emerging*correlation is not significant, however the coefficient sign is consistent with there being a liberalization effect for emerging market rivals. The coefficient for the number of days between the announcement and the listing suggests that the more time passes since the announcement took place, the more negative is the impact on the rival firm. Finally, we note a significant improvement in the fit of the regression once all variables are included in the specification. Overall, the results present a picture of rivals at cross-listing events where revised perceptions of growth opportunities are likely to be dominant in firm valuation.

\section{Conclusion}

In this paper we ask whether there are benefits or costs of cross-listing to other firms in the domestic country, by studying the stock price effects on rival firms associated with a cross-listing in the U.S. The evidence indicates that when a firm crosslists in the U.S., its primary rival in the home market that is not listed in the U.S. is hurt by the listing. Our results are consistent with the idea that firms cross-list as a means to 
reduce agency costs of controlling shareholders and thus are able to exploit growth opportunities as they have better access to external finance. Rival firms left behind are seen at a relative disadvantage to the cross-listing firms.

Theory suggests that there is a positive effect on rivals due to a decrease in the cost of capital that competes against the negative effects associated with rival firms being viewed at a relative disadvantage because of their decision not to list. The empirical evidence indicates that the negative spillover effect is the dominating effect on rival share prices. Rival firms tend to suffer when listing firms list their stock in the United States.

Our cross-sectional analysis provides support for both the positive risk sharing effect of cross-listing, and the negative growth opportunities effect. When we simultaneously test both hypotheses, the growth opportunities effect dominates, as we find that rival firms with greater growth prospects are hurt by more from the cross-listing. Our results thus support the idea that firms cross-list in the U.S. to bond with U.S. laws, reduce agency costs, and hence have better access to external capital and exploit opportunities for growth.

A public policy implication of these findings is that listing in the U.S. should be viewed as creating incentives for better disclosure and law enforcement in the home market. More transparent accounting and corporate governance standards, as well as stricter laws in the home market might serve as a partial substitute for a U.S. listing.

Given current institutional differences across countries, the effects of a U.S. listing are not all favorable for the home market of the listing firm. Those left behind without a U.S. listing tend to experience a negative price impact. 


\section{References}

Alexander, G., C. Eun, and S. Janakiramanan. “Asset Pricing and Dual Listing on Foreign Capital Markets: A Note.” Journal of Finance, 42 (1987), 151-158.

Bekaert, G., and C. Harvey. “Time-varying World Market Integration.” Journal of Finance 50 (1995), 403-444.

Bekaert, G., C. Harvey, C. Lundblad, and S. Siegel. “Global Growth Opportunities and Market Integration,” Journal of Finance, 62 (2007), 1081-1137.

Baker, H. K., J. Nofsinger, and D. Weaver. "International Cross-Listing and Visibility.” Journal of Financial and Quantitative Analysis, 37 (2002), 495-521.

Billett, M., T. King, and D. Mauer. "Growth Opportunities and the Choice of Leverage, Debt Maturity, and Covenants.” Journal of Finance 62 (2007), 697-730.

Bradford, B., A. D. Martin, and A. M. Whyte. “Competitive and Information Effects of Cross-Border Stock Listings.” Journal of Financial Research, 25 (2002), 399-413.

Cantale, S. “The Choice of a Foreign Market as a Signal,” INSEAD working paper (1996).

Chemmanur, T., and P. Fulghieri. “Competition and Cooperation Among Exchanges: A Theory of Cross-Listing and Endogenous Listing Standards,” Journal of Financial Economics, 82 (2006), 455-489.

Coffee Jr., J. C. “The Future as History: The Prospects for Global Convergence in Corporate Governance and its Implications.” Northwestern Law Review 93 (1999), 641-707. 
Coffee Jr., J. C. "Racing Towards the Top?: The Impact of Cross-Listings and Stock Market Competition on International Corporate Governance.” Columbia Law Review 102 (2002), 1757-1831.

Djankov, S., R. La Porta, F. Lopez-de-Silanes and A. Shleifer. "The Law and Economics of Self-Dealing”, NBER Working Paper 11883 (2005).

Doidge, C. "U.S. Cross-listings and the Private Benefits of Control: Evidence from Dual Class Firms.” Journal of Financial Economics 72 (2004), 519-554.

Doidge, C. G., A. Karolyi, and R. Stulz. "Why Are Foreign Firms Listed in the U.S. Worth More?.” Journal of Financial Economics 71 (2004), 205-238.

Doidge, C., A. Karolyi, K. Lins, D. Miller, and R. Stulz. "Private Benefits of Control, Ownership, and the Cross-Listing Decision.” Working Paper (2007).

Eaton, T., J. R. Nofsinger, and D. Weaver. "Disclosure and the Cost of Equity in International Cross Listing.” Review of Quantitative Finance and Accounting 29 (2007), 1-24.

Errunza, V. and E. Losq. “International Asset Prices Under Mild Segmentation.” Journal of Finance, 40 (1985), 105-124.

Errunza, V. and D. Miller. “Market Segmentation and the Cost of Capital in International Equity Markets.” Journal of Financial and Quantitative Analysis, 35 (2000), 577600.

Eun, C., S. Claessens, and K. Jun. "Pricing externalities in the world financial markets: Theory and policy implications.” Pacific-Basin Finance Journal, 3 (1995), 31-55.

Fernandes, N. “Market Liberalization: Spillover From ADRs and Implications for Local Markets.” Working paper. (2003). 
Foerster, S. and G. A. Karolyi. “The Effects of Market Segmentation and Investor Recognition on Asset Prices: Evidence from Foreign Stocks Listing in the United States.” Journal of Finance, 54 (1999), 981-1013.

Fuerst, O. “A Theoretical Analysis of the Investor Protection Regulations Argument for Global Listing of Stocks,” Yale University working paper (1998).

Huddart, S., J. Hughes and M. Brunnermeier. “Disclosure Requirements and Stock Exchange Listing Choice in an International Context”, Journal of Accounting and Economics 26 (1999), 237-269.

Karolyi, G. A. "Why Do Companies List Shares Abroad? A Survey of the Evidence and its Managerial Implications.” Financial Markets, Institutions and Instruments 7 (1998), 1-60.

Karolyi, G.A “The Role of ADRs in the Development of Emerging Equity Markets.” Review of Economic and Statistics 86 (2004), 670-690.

La Porta, R., F. Lopez-de-Silanes, A. Shleifer, and R. Vishny. “Investor Protection and Corporate Governance.” Journal of Financial Economics 58 (2000), 3-29.

La Porta, R., F. Lopez-de-Silanes, A. Shleifer, and R. Vishny. "Law and Finance.” Journal of Political Economy 106 (1998), 1113-1155.

La Porta, R., F. Lopez-de-Silanes, A. Shleifer, and R. Vishny. "Legal Determinants of External Finance.” Journal of Finance 52 (1997), 1131-1155.

Lang, M., J. Raedy and M. Yetman. "How Representative Are Firms That Are Cross Listed in the United States? An Analysis of Accounting Quality.” Journal of Accounting Research 41 (2003), 363-386. 
Lee, D. W. "Why does Shareholder Wealth Increase when Non-U.S. Firms Announce their Listing in the U.S.?” Working Paper, University of Kentucky. (2004).

Levine, R., and S. Schmukler. "Migration, Spillovers, and Trade Diversion: The Impact of Internationalization on Domestic Stock Market Activity.” Journal of Banking and Finance 31 (2007), 1595-1612.

Miller, D. P. “The Market Reaction to International Cross-listings: Evidence from Depositary Receipts.” Journal of Financial Economics 51 (1999), 103-123.

Moel, A. "The Role of Information Disclosure on Stock Market Listing Decisions: The Case of Foreign Firms Listing in the US,” Harvard University working paper (1999).

Pagano, M., Röell, A. and J. Zechner. “The Geography of Equity Listing: Why Do Companies List Abroad?” Journal of Finance 57 (2002), 2651-2694.

Patell, J. M. “Corporate Forecasts of Earnings Per Share and Stock Price Behavior: Empirical Tests.” Journal of Accounting Research, 14 (1976), 246-274.

Reese, W. and M. Weisbach. "Protection of Minority Shareholder Interests, Crosslistings in the United States and Subsequent Equity Offerings.” Journal of Financial Economics 66 (2002), 65-104.

Stulz, R. "Globalization, Corporate Finance and the Cost of Capital," Journal of Applied Corporate Finance, 12 (1999), 8-25. 
Table 1

Descriptive Statistics for the Sample.

This table summarizes the sample data. There are a total of 146 firms in the sample, coming from 21 countries. The time period covered is between 1986 and 2002. The table presents the data composition by region, industry, country, year listed in the U.S., emerging and developed market firms, and firms from civil law and common law countries.

\begin{tabular}{|c|c|c|c|}
\hline$\underline{\text { Region }}$ & Number of Firms & $\underline{\text { Industry }}$ & Number of Firms \\
\hline Latin America & 12 & Resources & 11 \\
\hline Asia & 22 & Basic Industries & 17 \\
\hline Europe & 57 & General Industries & 7 \\
\hline Oceania & 7 & Consumer Goods & 32 \\
\hline \multirow[t]{4}{*}{ Canada } & 48 & Services & 20 \\
\hline & & Utilities & 7 \\
\hline & & Information Technology & 20 \\
\hline & & Financials & 32 \\
\hline Country & & $\underline{\text { Year Listed }}$ & \\
\hline Argentina & 2 & 1986 & 2 \\
\hline Australia & 7 & 1987 & 6 \\
\hline Belgium & 1 & 1988 & 2 \\
\hline Brazil & 5 & 1989 & 5 \\
\hline Canada & 48 & 1990 & 1 \\
\hline Chile & 4 & 1991 & 3 \\
\hline Finland & 1 & 1992 & 3 \\
\hline France & 8 & 1993 & 4 \\
\hline Germany & 8 & 1994 & 7 \\
\hline India & 7 & 1995 & 5 \\
\hline Ireland & 2 & 1996 & 17 \\
\hline Italy & 3 & 1997 & 8 \\
\hline Japan & 8 & 1998 & 5 \\
\hline Korea & 1 & 1999 & 11 \\
\hline Mexico & 1 & 2000 & 30 \\
\hline Netherlands & 1 & 2001 & 22 \\
\hline South Korea & 1 & 2002 & 15 \\
\hline Spain & 1 & & \\
\hline Switzerland & 5 & & \\
\hline Taiwan & 5 & & \\
\hline UK & 27 & & \\
\hline Emerging & 25 & & \\
\hline Developed & 121 & & \\
\hline Civil Law & 54 & & \\
\hline Common Law & 92 & & \\
\hline
\end{tabular}


Table 2

\section{Mean Cumulative Abnormal Returns for Listing Event}

This table presents the mean cumulative abnormal returns around the listing date for 146 rival firms in our sample. Results are presented for the windows $(-5,-1),(-5,+1),(0,0),(+1,+5)$ and $(-5,+5)$, where day 0 represents listing day. The third column is the precision-weighted cumulative mean abnormal return. The positive column reflects how many firms had positive cumulative abnormal returns in that respective window. The $\mathrm{Z}$ test statistic is a test of the significance of the mean cumulative abnormal return. The Generalized Sign $\mathrm{Z}$ is a test with the null hypothesis that the fraction of positive cumulative returns is the same as in the estimation period. The symbols *,**, and *** denote statistical significance at the $10 \%, 5 \%$, and $1 \%$ levels, respectively, using a 2-tail test.

\begin{tabular}{lccccc}
\hline \multicolumn{1}{c}{ Days } & $\begin{array}{c}\text { Mean } \\
\text { Cumulative } \\
\text { Abnormal } \\
\text { Return }\end{array}$ & $\begin{array}{c}\text { Precision } \\
\text { Weighted } \\
\text { CAAR }\end{array}$ & Positive & Z & $\begin{array}{c}\text { Generalized } \\
\text { Sign Z }\end{array}$ \\
\hline$(-5,-1)$ & $-1.37 \%$ & $-0.68 \%$ & 60 & $-1.9990^{* *}$ & $-1.8181^{*}$ \\
$(-5,+1)$ & $-1.59 \%$ & $-0.93 \%$ & 60 & $-2.2944^{* *}$ & $-1.8181^{*}$ \\
$(0,0)$ & $-0.18 \%$ & $-0.26 \%$ & 63 & $-1.7005^{*}$ & -1.3214 \\
$(+1,+5)$ & $-0.65 \%$ & $-0.45 \%$ & 58 & -1.3206 & $-2.1493^{* *}$ \\
$(-5,+5)$ & $-2.20 \%$ & $-1.39 \%$ & 59 & $-2.7508^{* * *}$ & $-1.9837^{* *}$ \\
\hline
\end{tabular}

Table 3

\section{Mean Cumulative Abnormal Returns for Announcement Event}

This table presents the mean cumulative abnormal returns around the announcement date for 144 rival firms in our sample. Results are presented for the windows $(-5,-1),(-5,+1),(0,0),(+1,+5)$ and $(-5,+5)$, where day 0 represents announcement day. The third column is the precision-weighted cumulative mean abnormal return. The positive column reflects how many firms had positive cumulative abnormal returns on that respective window. The $\mathrm{Z}$ test statistic is a test on the significance of the mean cumulative abnormal return. The Generalized Sign $\mathrm{Z}$ is a test with the null hypothesis that the fraction of positive cumulative returns is the same as in the estimation period. The symbols ***, and *** denote statistical significance at the $10 \%, 5 \%$, and $1 \%$ levels, respectively, using a 2 -tail test.

\begin{tabular}{lccccc}
\hline \multicolumn{1}{c}{ Days } & $\begin{array}{c}\text { Mean } \\
\text { Cumulative } \\
\text { Abnormal } \\
\text { Return }\end{array}$ & $\begin{array}{c}\text { Precision } \\
\text { Weighted } \\
\text { CAAR }\end{array}$ & Positive & Z & \multicolumn{1}{c}{$\begin{array}{c}\text { Generalized } \\
\text { Sign Z }\end{array}$} \\
\hline \multicolumn{7}{c}{ CA,-1) } & $-0.03 \%$ & $0.31 \%$ & 70 & 0.9040 & 0.2236 \\
$(-5,+1)$ & $-0.29 \%$ & $-0.01 \%$ & 66 & -0.0222 & -0.4438 \\
$(0,0)$ & $-0.32 \%$ & $-0.36 \%$ & 54 & $-2.3419 * *$ & $-2.4460 * *$ \\
$(+1,+5)$ & $-0.10 \%$ & $0.22 \%$ & 63 & 0.6479 & -0.9444 \\
$(-5,+5)$ & $-0.45 \%$ & $0.18 \%$ & 64 & 0.3402 & -0.7775 \\
\hline
\end{tabular}


Table 4

Listing and Announcement Event Abnormal Returns for Developed and Emerging Markets.

This table presents the mean cumulative abnormal returns around the listing and announcement date for the 121 developed market firms and the 25 emerging markets firms separately. Panel A presents the results for the listing event and Panel B for the announcement event. Results are presented over the windows $(-5,-1)$, $(-5,+1),(0,0),(+1,+5)$ and $(-5,+5)$, where day 0 represents event day. The $Z$ test statistic is a test of the significance of the mean cumulative abnormal return. The Generalized Sign $\mathrm{Z}$ is a test with the null hypothesis that the fraction of positive cumulative returns is the same as in the estimation period. The symbols $*, * *$, and $* * *$ denote statistical significance of the abnormal returns at the $10 \%, 5 \%$, and $1 \%$ levels, respectively, using a 2-tail test. The last column presents the difference in the mean cumulative abnormal returns of the developed and emerging market samples. A test of the difference between the means of both samples was conducted, with no statistically significant differences found.

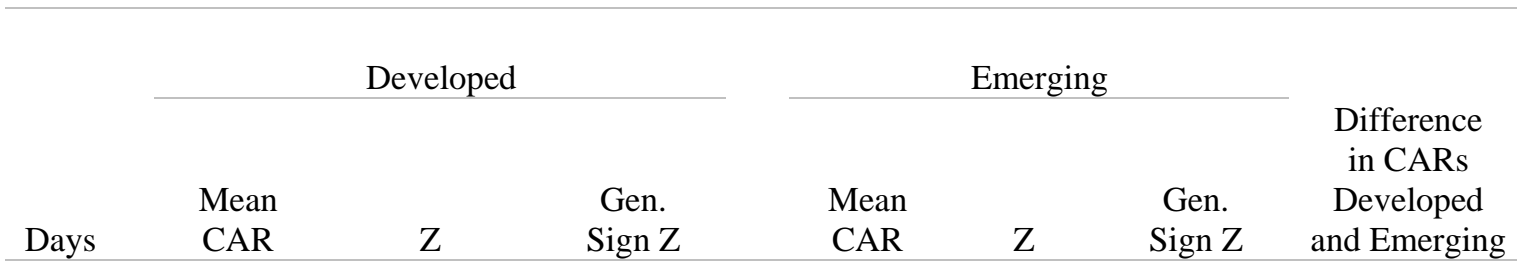

Panel A. Listing Event

\begin{tabular}{llllllll}
\hline$(-5,-1)$ & $-1.30 \%$ & $-1.9693^{* *}$ & $-1.7892^{*}$ & $-1.67 \%$ & -0.4918 & -0.4587 & $0.37 \%$ \\
$(-5,+1)$ & $-1.68 \%$ & $-2.4731^{* *}$ & $-1.9710^{* *}$ & $-1.15 \%$ & -0.0865 & -0.0563 & $-0.53 \%$ \\
$(0,0)$ & $-0.20 \%$ & $-1.6601 *$ & -1.0619 & $-0.05 \%$ & -0.4522 & -0.8611 & $-0.15 \%$ \\
$(+1,+5)$ & $-0.85 \%$ & -1.5654 & $-2.1529 * *$ & $0.28 \%$ & 0.269 & -0.4587 & $-1.13 \%$ \\
$(-5,+5)$ & $-2.35 \%$ & $-2.8836 * * *$ & $-1.9710 * *$ & $-1.44 \%$ & -0.2865 & -0.4587 & $-0.91 \%$
\end{tabular}

Panel B. Announcement Event

$\begin{array}{llllclcc}(-5,-1) & -0.08 \% & 0.8166 & 0.0049 & 0.19 \% & 0.3883 & 0.531 & -0.27 \% \\ (-5,+1) & -0.43 \% & -0.1285 & -0.7287 & 0.36 \% & 0.232 & 0.531 & -0.79 \% \\ (0,0) & -0.31 \% & -1.9848 * * & -2.1959 * * & -0.38 \% & -1.2969 & -1.0862 & 0.07 \% \\ (+1,+5) & 0.30 \% & 1.3719 & -0.1785 & -1.98 \% & -1.4734 & -1.8947 * & 2.28 \% \\ (-5,+5) & -0.09 \% & 0.8771 & 0.0049 & -2.17 \% & -1.1226 & -1.8947 * & 2.08 \%\end{array}$


Table 5

\section{Cross-sectional differences in cumulative abnormal returns}

Risk sharing hypothesis

The table presents the results of a series of regressions where the dependent variable is the percentage cumulative abnormal returns around the $(-5,+5)$ day window around the listing and announcement dates for rival firms. The number inside each cell represents the coefficient estimate resulting from an OLS regression. The symbols *,**, and *** denote statistical significance of the coefficients at the $10 \%, 5 \%$ and $1 \%$ levels, respectively, using a 2-tail test and Newey-West standard errors adjustments.

\section{Panel A. Listing Date}

\begin{tabular}{llllll}
\hline & Model 1 & Model 2 & Model 3 & Model 4 & Model 5 \\
\hline Constant & -1.45 & -1.36 & 1.25 & 0.90 & 0.34 \\
$\begin{array}{l}\text { Correlation } \\
\text { Correlation*Emerging }\end{array}$ & 2.73 & 2.33 & & & 1.59 \\
$\begin{array}{l}\text { Time of Listing } \\
\text { Time of Listing*Emerging }\end{array}$ & & 1.89 & & & 2.13 \\
Emerging & & & -0.20 & -0.17 & -0.13 \\
$\begin{array}{l}\text { Days Between } \\
\text { Size Rival }\end{array}$ & 1.54 & 0.81 & 2.23 & -0.58 & -0.63 \\
Foreign Sales & -0.01 & -0.01 & -0.01 & -0.01 & 10.06 \\
& $\mathbf{0 . 0 9 *}$ & $\mathbf{0 . 0 9 * *}$ & $\mathbf{0 . 1 2 * * *}$ & $\mathbf{0 . 1 2 * * *}$ & -0.01 \\
$\mathrm{R}^{2}$ & -0.02 & -0.02 & -0.02 & -0.02 & -0.02 \\
Adj R & & & & & \\
Obs. & 0.12 & 0.12 & 0.13 & 0.13 & 0.14 \\
& 0.05 & 0.03 & 0.06 & 0.05 & 0.01 \\
\hline
\end{tabular}

Panel B. Announcement Date

\begin{tabular}{llllll}
\hline & Model 1 & Model 2 & Model 3 & Model 4 & Model 5 \\
\hline Constant & 0.59 & 1.69 & 1.93 & 0.67 & 2.34 \\
Correlation & -0.94 & -5.74 & & & -6.20 \\
$\begin{array}{l}\text { Correlation*Emerging } \\
\text { Time of Listing }\end{array}$ & & $\mathbf{2 5 . 9 4 * * *}$ & & & $\mathbf{2 2 . 3 1 ^ { * * }}$ \\
$\begin{array}{l}\text { Time of Listing*Emerging } \\
\text { Emerging }\end{array}$ & & & -0.13 & -0.03 & -0.05 \\
$\begin{array}{l}\text { Days Between } \\
\text { Size Rival }\end{array}$ & -3.54 & $-\mathbf{1 3 . 0 2 * * *}$ & -3.55 & -1.72 & -1.00 \\
Foreign Sales & -0.01 & -0.01 & -0.01 & -0.06 & 2.54 \\
& 0.04 & 0.07 & 0.04 & 0.04 & -0.01 \\
$\mathrm{R}^{2}$ & 0.01 & 0.01 & 0.01 & 0.01 & 0.01 \\
Adj R & & & & & \\
Obs. & 0.09 & 0.17 & 0.08 & 0.11 & 0.18 \\
& 0.00 & 0.07 & 0.00 & 0.02 & 0.05 \\
\hline & 60 & 60 & 65 & 65 & 60 \\
\hline
\end{tabular}


Table 6

\section{Cross-sectional differences in cumulative abnormal returns} Industry determinants of negative spillovers

The table presents the results of a series of regressions where the dependent variable is the percentage cumulative abnormal returns around the $(-5,+5)$ day window around the listing and announcement dates for rival firms. The number inside each cell represents the coefficient estimate resulting from an OLS regression. The symbols *,**, and *** denote statistical significance of the coefficients at the $10 \%$, 5\% and $1 \%$ levels, respectively, using a 2-tail test and Newey-West standard errors adjustments.

\section{Panel A. Listing Date}

\begin{tabular}{|c|c|c|}
\hline & Model 1 & Model 2 \\
\hline Constant & -1.32 & 0.17 \\
\hline Industry PE & -0.004 & -0.065 \\
\hline IndustryPE*emerging & & 0.06 \\
\hline Emerging & 1.64 & -0.44 \\
\hline Days Between & $-0.01 *$ & $-0.01 *$ \\
\hline Size Rival & $0.11 * *$ & 0.10 \\
\hline Foreign Sales & -0.02 & -0.02 \\
\hline $\mathrm{R}^{2}$ & 0.11 & 0.15 \\
\hline Adj $\mathrm{R}^{2}$ & 0.04 & 0.06 \\
\hline Obs. & 65 & 65 \\
\hline
\end{tabular}

Panel B. Announcement Date

\begin{tabular}{lll}
\hline & Model 1 & Model 2 \\
\hline Constant & & 1.81 \\
Industry PE & 0.14 & $\mathbf{- 0 . 0 6 5 *}$ \\
IndustryPE*emerging & $\mathbf{- 0 . 0 0 4 * *}$ & $\mathbf{0 . 0 6 1 * *}$ \\
Emerging & & -4.96 \\
Days Between & -2.01 & 0.00 \\
Size Rival & -0.01 & 0.03 \\
Foreign Sales & 0.04 & 0.01 \\
$\mathrm{R}^{2}$ & 0.01 & 0.17 \\
Adj R & & 0.07 \\
Obs. & 0.11 & 60 \\
\end{tabular}


Table 7

\section{Cross-sectional differences in cumulative abnormal returns}

Country determinants of negative spillovers

The table presents the results of a series of regressions where the dependent variable is the percentage cumulative abnormal returns around the $(-5,+5)$ day window around the listing and announcement dates for rival firms. The number inside each cell represents the coefficient estimate resulting from an OLS regression. The symbols *,**, and $* * *$ denote statistical significance of the coefficients at the $10 \%, 5 \%$ and $1 \%$ levels, respectively, using a 2-tail test and Newey-West standard errors adjustments.

Panel A. Listing Date

\begin{tabular}{|c|c|c|c|c|c|c|c|}
\hline & Model 1 & Model 2 & Model 3 & Model 4 & Model 5 & Model 6 & Model 7 \\
\hline Constant & -1.43 & $-16.08 * *$ & -5.51 & $8.83^{* *}$ & $28.28 * *$ & $-66.91 * * *$ & -21.50 \\
\hline Civil & 2.75 & & & & & & -2.06 \\
\hline Rule of Law & & $1.55 * *$ & & & & & -1.30 \\
\hline Corruption & & & 0.48 & & & & 0.24 \\
\hline Antidirector & & & & $-2.34 * * *$ & & & -2.09 \\
\hline Efficiency & & & & & $-3.11 * *$ & & -2.34 \\
\hline Risk of Expropriation & & & & & & $6.80 * *$ & $6.42 *$ \\
\hline Emerging & 1.21 & 6.86** & 3.60 & 2.76 & -5.47 & $11.71 * * *$ & 3.57 \\
\hline Days Between & $-0.01 *$ & -0.01 & -0.01 & $-0.02 * *$ & $-0.01 *$ & $-0.01 *$ & $-0.01 *$ \\
\hline Size Rival & $0.11 * * *$ & $0.13 * * *$ & $0.12 * *$ & $0.12 * * *$ & $0.12 * * *$ & $0.10 * *$ & $0.10 * *$ \\
\hline Foreign Sales & -0.03 & -0.02 & -0.02 & -0.03 & -0.02 & -0.03 & -0.03 \\
\hline $\mathrm{R}^{2}$ & 0.14 & 0.15 & 0.11 & 0.17 & 0.16 & 0.17 & 0.21 \\
\hline Adj $R^{2}$ & 0.07 & 0.08 & 0.04 & 0.11 & 0.10 & 0.10 & 0.07 \\
\hline Obs. & 69 & 70 & 69 & 70 & 69 & 69 & 69 \\
\hline
\end{tabular}

Panel B. Announcement Date

\begin{tabular}{|c|c|c|c|c|c|c|c|}
\hline & Model 1 & Model 2 & Model 3 & Model 4 & Model 5 & Model 6 & Model 7 \\
\hline Constant & 0.21 & $-25.02 * * *$ & $-26.96 * *$ & 7.63 & -0.86 & $-94.00 * * *$ & -57.69 \\
\hline Civil & 0.15 & & & & & & -3.38 \\
\hline Rule of Law & & $2.67 * * *$ & & & & & -0.89 \\
\hline Corruption & & & $3.13^{* *}$ & & & & 2.92 \\
\hline Antidirector & & & & -1.70 & & & -4.16 \\
\hline Efficiency & & & & & 0.11 & & 1.94 \\
\hline Risk of Expropriation & & & & & & $9.78 * * *$ & 4.23 \\
\hline Emerging & -4.02 & 3.95 & 8.84 & -3.57 & -3.70 & $9.29 * *$ & $17.47 * *$ \\
\hline Days Between & -0.01 & -0.01 & 0.00 & -0.01 & -0.01 & -0.01 & -0.01 \\
\hline Size Rival & 0.04 & 0.06 & 0.05 & 0.05 & 0.04 & 0.01 & 0.04 \\
\hline Foreign Sales & 0.01 & 0.00 & 0.01 & 0.00 & 0.01 & -0.01 & -0.01 \\
\hline $\mathrm{R}^{2}$ & 0.07 & 0.18 & 0.19 & 0.10 & 0.07 & 0.18 & 0.26 \\
\hline Adj $R^{2}$ & -0.01 & 0.11 & 0.11 & 0.03 & -0.01 & 0.11 & 0.12 \\
\hline Obs. & 64 & 64 & 64 & 65 & 64 & 64 & 64 \\
\hline
\end{tabular}


Table 8

\section{Cross-sectional differences in cumulative abnormal returns} Company determinants of negative spillovers

The table presents the results of a series of regressions where the dependent variable is the percentage cumulative abnormal returns around the $(-5,+5)$ day window around the listing and announcement dates for rival firms. The number inside each cell represents the coefficient estimate resulting from an OLS regression. The symbols *,**, and *** denote statistical significance of the coefficients at the $10 \%, 5 \%$ and $1 \%$ levels, respectively, using a 2-tail test and Newey-West standard errors adjustments.

Panel A. Listing Date

\begin{tabular}{|c|c|c|c|c|c|c|}
\hline & Model 1 & Model 2 & Model 3 & Model 4 & Model 5 & Model 6 \\
\hline Constant & -0.61 & -0.40 & -0.46 & -0.48 & -0.88 & -0.54 \\
\hline PE ratio rival & $-0.03^{*}$ & $-0.03^{* *}$ & & & & \\
\hline Rival's Growth & & & -0.01 & -0.003 & & \\
\hline Rival Market to book & & & & & $-0.10 * *$ & -0.20 \\
\hline $\mathrm{PE} *$ Emerging & & 0.05 & & & & \\
\hline Growth * Emerging & & & & -0.15 & & \\
\hline MB * Emerging & & & & & & 0.10 \\
\hline Emerging & 0.90 & -0.70 & 1.10 & 6.18 & 3.24 & 2.80 \\
\hline Days Between & -0.01 & -0.01 & $-0.01 *$ & $-0.01 *$ & $-0.01 *$ & $-0.01 *$ \\
\hline Size Rival & 0.08 & 0.08 & 0.11* & 0.11* & $0.12 *$ & 0.13* \\
\hline Foreign Sales & -0.03 & -0.03 & -0.03 & -0.03 & -0.02 & -0.02 \\
\hline $\mathrm{R}^{2}$ & 0.09 & 0.10 & 0.12 & 0.17 & 0.17 & 0.17 \\
\hline Adj $R^{2}$ & 0.01 & 0.00 & 0.05 & 0.09 & 0.08 & 0.07 \\
\hline Obs. & 62 & 62 & 65 & 65 & 56 & 56 \\
\hline
\end{tabular}

Panel B. Announcement Date

\begin{tabular}{|c|c|c|c|c|c|c|}
\hline & Model 1 & Model 2 & Model 3 & Model 4 & Model 5 & Model 6 \\
\hline Constant & 2.82 & 2.79 & 1.65 & 1.82 & 1.81 & 2.93 \\
\hline $\mathrm{PE}$ ratio rival & $-0.03^{* *}$ & $-0.03^{* *}$ & & & & \\
\hline Rival's Growth & & & $-0.02 *$ & $-0.02 *$ & & \\
\hline Rival Market to book & & & & & -0.04 & -0.35 \\
\hline PE * Emerging & & -0.03 & & & & \\
\hline Growth * Emerging & & & & $0.11 *$ & & \\
\hline MB * Emerging & & & & & & 0.32 \\
\hline Emerging & -5.74 & -4.89 & -6.23 & -11.74 & -3.63 & -4.92 \\
\hline Days Between & -0.01 & -0.01 & -0.01 & -0.01 & -0.01 & -0.01 \\
\hline Size Rival & 0.05 & 0.05 & 0.02 & 0.02 & 0.04 & 0.05 \\
\hline Foreign Sales & -0.01 & -0.01 & -0.01 & -0.01 & -0.01 & -0.01 \\
\hline $\mathrm{R}^{2}$ & 0.17 & 0.17 & 0.14 & 0.16 & 0.13 & 0.14 \\
\hline Adj $R^{2}$ & 0.09 & 0.07 & 0.06 & 0.06 & 0.04 & 0.03 \\
\hline Obs. & 58 & 58 & 60 & 60 & 54 & 54 \\
\hline
\end{tabular}


Table 9

\section{Cross-sectional differences in cumulative abnormal returns} Risk Sharing vs. Growth Opportunities

The table presents the results of a series of regressions where the dependent variable is the percentage cumulative abnormal returns around the $(-5,+5)$ day window around the listing and announcement dates for rival firms. The number inside each cell represents the coefficient estimate resulting from an OLS regression. The symbols *, **, and *** denote statistical significance of the coefficients at the $10 \%, 5 \%$ and $1 \%$ levels, respectively, using a 2-tail test and Newey-West standard errors adjustments.

\begin{tabular}{lll}
\hline & Listing Date & Announcement Date \\
\hline & & \\
Constant & -18.77 & -13.65 \\
Rule of Law & 1.92 & 1.84 \\
Correlation & 7.31 & 0.81 \\
Correlation * Emerging & 1.10 & 15.78 \\
PE Industry & 0.00 & 0.00 \\
PE Rival & $\mathbf{- 0 . 0 3 * * *}$ & $\mathbf{- 0 . 0 3 * *}$ \\
Rival's Growth & $\mathbf{- 0 . 0 7 * * *}$ & $\mathbf{- 0 . 0 4 * * *}$ \\
Emerging & 6.93 & -6.01 \\
Size rival & 0.03 & 0.04 \\
Days between & $\mathbf{- 0 . 0 1 * *}$ & -0.01 \\
Foreign Sales & 0.00 & 0.00 \\
$\mathrm{R}^{2}$ & & \\
Adj R & & 0.39 \\
Obs. & 0.26 & 0.22 \\
\end{tabular}




\section{CESifo Working Paper Series}

for full list see www.cesifo-group.org/wp

(address: Poschingerstr. 5, 81679 Munich, Germany, office@cesifo.de)

2108 Torben M. Andersen and Michael Svarer, Flexicurity - Labour Market Performance in Denmark, October 2007

2109 Jonathan P. Thomas and Tim Worrall, Limited Commitment Models of the Labor Market, October 2007

2110 Carlos Pestana Barros, Guglielmo Maria Caporale and Luis A. Gil-Alana, Identification of Segments of European Banks with a Latent Class Frontier Model, October 2007

2111 Felicitas Nowak-Lehmann D., Sebastian Vollmer and Immaculada Martínez-Zarzoso, Competitiveness - A Comparison of China and Mexico, October 2007

2112 Mark Mink, Jan P.A.M. Jacobs and Jakob de Haan, Measuring Synchronicity and Comovement of Business Cycles with an Application to the Euro Area, October 2007

2113 Ossip Hühnerbein and Tobias Seidel, Intra-regional Tax Competition and Economic Geography, October 2007

2114 Christian Keuschnigg, Exports, Foreign Direct Investment and the Costs of Corporate Taxation, October 2007

2115 Werner Bönte, Oliver Falck and Stephan Heblich, Demography and Innovative Entrepreneurship, October 2007

2116 Katrin Assenmacher-Wesche and M. Hashem Pesaran, Assessing Forecast Uncertainties in a VECX Model for Switzerland: An Exercise in Forecast Combination across Models and Observation Windows, October 2007

2117 Ben Lockwood, Voting, Lobbying, and the Decentralization Theorem, October 2007

2118 Andrea Ichino, Guido Schwerdt, Rudolf Winter-Ebmer and Josef Zweimüller, Too Old to Work, too Young to Retire?, October 2007

2119 Wolfgang Eggert, Tim Krieger and Volker Meier, Education, Unemployment and Migration, October 2007

2120 Stefan Napel and Mika Widgrén, The European Commission - Appointment, Preferences, and Institutional Relations, October 2007

2121 Bertil Holmlund and Martin Söderström, Estimating Income Responses to Tax Changes: A Dynamic Panel Data Approach, October 2007

2122 Doina Maria Radulescu, From Separate Accounting to Formula Apportionment: Analysis in a Dynamic Framework, October 2007 
2123 Jelle Brouwer, Richard Paap and Jean-Marie Viaene, The Trade and FDI Effects of EMU Enlargement, October 2007

2124 Kurt R. Brekke, Luigi Siciliani and Odd Rune Straume, Competition and Waiting Times in Hospital Markets, October 2007

2125 Alexis Direr, Flexible Life Annuities, October 2007

2126 Johannes Becker and Clemens Fuest, Quality versus Quantity - The Composition Effect of Corporate Taxation on Foreign Direct Investment, October 2007

2127 Balázs Égert, Real Convergence, Price Level Convergence and Inflation Differentials in Europe, October 2007

2128 Marko Koethenbuerger, Revisiting the "Decentralization Theorem" - On the Role of Externalities, October 2007

2129 Axel Dreher, Silvia Marchesi and James Raymond Vreeland, The Politics of IMF Forecasts, October 2007

2130 Andreas Knabe and Ronnie Schöb, Subsidizing Extra Jobs: Promoting Employment by Taming the Unions, October 2007

2131 Michel Beine and Bertrand Candelon, Liberalization and Stock Market Co-Movement between Emerging Economies, October 2007

2132 Dieter M. Urban, FDI Technology Spillovers and Wages, October 2007

2133 Valentina Bosetti, Carlo Carraro, Emanuele Massetti and Massimo Tavoni, Optimal Energy Investment and R\&D Strategies to Stabilise Greenhouse Gas Atmospheric Concentrations, October 2007

2134 David-Jan Jansen and Jakob de Haan, The Importance of Being Vigilant: Has ECB Communication Influenced Euro Area Inflation Expectations?, October 2007

2135 Oliver Falck, Heavyweights - The Impact of Large Businesses on Productivity Growth, October 2007

2136 Xavier Freixas and Bruno M. Parigi, Banking Regulation and Prompt Corrective Action, November 2007

2137 Jan K. Brueckner, Partial Fiscal Decentralization, November 2007

2138 Silvia Console Battilana, Uncovered Power: External Agenda Setting, Sophisticated Voting, and Transnational Lobbying, November 2007

2139 Alan J. Auerbach, Michael P. Devereux and Helen Simpson, Taxing Corporate Income, November 2007 
2140 Lorenzo Cappellari, Paolo Ghinetti and Gilberto Turati, On Time and Money Donations, November 2007

2141 Roel Beetsma and Heikki Oksanen, Pension Systems, Ageing and the Stability and Growth Pact, November 2007

2142 Hikaru Ogawa and David E. Wildasin, Think Locally, Act Locally: Spillovers, Spillbacks, and Efficient Decentralized Policymaking, November 2007

2143 Alessandro Cigno, A Theoretical Analysis of the Effects of Legislation on Marriage, Fertility, Domestic Division of Labour, and the Education of Children, November 2007

2144 Kai A. Konrad, Mobile Tax Base as a Global Common, November 2007

2145 Ola Kvaløy and Trond E. Olsen, The Rise of Individual Performance Pay, November 2007

2146 Guglielmo Maria Caporale, Yannis Georgellis, Nicholas Tsitsianis and Ya Ping Yin, Income and Happiness across Europe: Do Reference Values Matter?, November 2007

2147 Dan Anderberg, Tax Credits, Income Support and Partnership Decisions, November 2007

2148 Andreas Irmen and Rainer Klump, Factor Substitution, Income Distribution, and Growth in a Generalized Neoclassical Model, November 2007

2149 Lorenz Blume, Jens Müller and Stefan Voigt, The Economic Effects of Direct Democracy - A First Global Assessment, November 2007

2150 Axel Dreher, Pierre-Guillaume Méon and Friedrich Schneider, The Devil is in the Shadow - Do Institutions Affect Income and Productivity or only Official Income and Official Productivity?, November 2007

2151 Valentina Bosetti, Carlo Carraro, Emanuele Massetti and Massimo Tavoni, International Energy R\&D Spillovers and the Economics of Greenhouse Gas Atmospheric Stabilization, November 2007

2152 Balázs Égert and Dubravko Mihaljek, Determinants of House Prices in Central and Eastern Europe, November 2007

2153 Christa Hainz and Hendrik Hakenes, The Politician and his Banker, November 2007

2154 Josef Falkinger, Distribution and Use of Knowledge under the "Laws of the Web", December 2007

2155 Thorvaldur Gylfason and Eduard Hochreiter, Growing Apart? A Tale of Two Republics: Estonia and Georgia, December 2007

2156 Morris A. Davis and François Ortalo-Magné, Household Expenditures, Wages, Rents, December 2007 
2157 Andreas Haufler and Christian Schulte, Merger Policy and Tax Competition, December 2007

2158 Marko Köthenbürger and Panu Poutvaara, Rent Taxation and its Intertemporal Welfare Effects in a Small Open Economy, December 2007

2159 Betsey Stevenson, Title IX and the Evolution of High School Sports, December 2007

2160 Stergios Skaperdas and Samarth Vaidya, Persuasion as a Contest, December 2007

2161 Morten Bennedsen and Christian Schultz, Arm’s Length Provision of Public Services, December 2007

2162 Bas Jacobs, Optimal Redistributive Tax and Education Policies in General Equilibrium, December 2007

2163 Christian Jaag, Christian Keuschnigg and Mirela Keuschnigg, Pension Reform, Retirement and Life-Cycle Unemployment, December 2007

2164 Dieter M. Urban, Terms of Trade, Catch-up, and Home Market Effect: The Example of Japan, December 2007

2165 Marcelo Resende and Rodrigo M. Zeidan, Lionel Robbins: A Methodological Reappraisal, December 2007

2166 Samuel Bentolila, Juan J. Dolado and Juan F. Jimeno, Does Immigration Affect the Phillips Curve? Some Evidence for Spain, December 2007

2167 Rainald Borck, Federalism, Fertility and Growth, December 2007

2168 Erkki Koskela and Jan König, Strategic Outsourcing, Profit Sharing and Equilibrium Unemployment, December 2007

2169 Egil Matsen and Øystein Thøgersen, Habit Formation, Strategic Extremism and Debt Policy, December 2007

2170 Torben M. Andersen and Allan Sørensen, Product Market Integration and Income Taxation: Distortions and Gains from Trade, December 2007

2171 J. Atsu Amegashie, American Idol: Should it be a Singing Contest or a Popularity Contest?, December 2007

2172 Patricia Apps and Ray Rees, Household Models: An Historical Perspective, December 2007

2173 Ben Greiner, Axel Ockenfels and Peter Werner, The Dynamic Interplay of Inequality and Trust - An Experimental Study, December 2007

2174 Michael Melvin and Magali Valero, The Dark Side of International Cross-Listing: Effects on Rival Firms at Home, December 2007 